\title{
Test Plan and Procedure for the Examination of Tank 241-AY-101 Multi-Probe Corrosion Monitoring System
}

\author{
R. B. Wyrwas \\ J. S. Page \\ G. A. Cooke \\ Washington River Protection Solutions LLC
}

Date Published

February 2012

Prepared for the U.S. Department of Energy

Office of River Protection

Contract No. DE-AC27-08RV14800 
LAB-RPT-12-00005

Revision 0

TRADEMARK DISCLAIMER

Reference herein to any specific commercial product, process, or service by tradename, trademark, manufacturer, or otherwise, does not necessarily constitute or imply its endorsement, recommendation, or favoring by the United States Government or any agency thereof or its contractors or subcontractors.

This report has been reproduced from the best available copy.

Printed in the United States of America 


\section{Table of Contents}

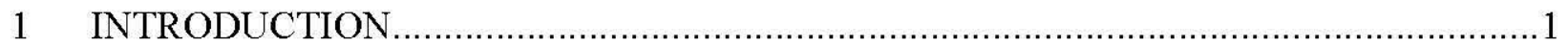

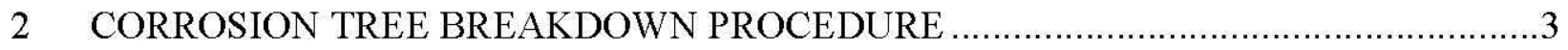

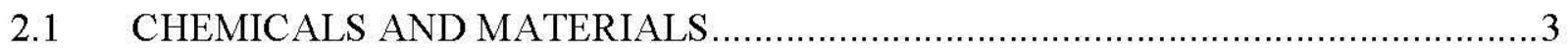

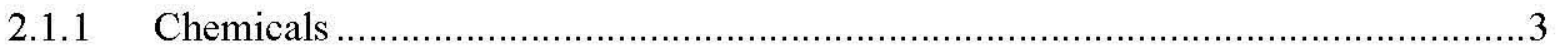

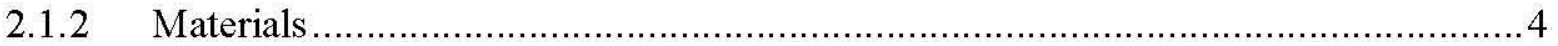

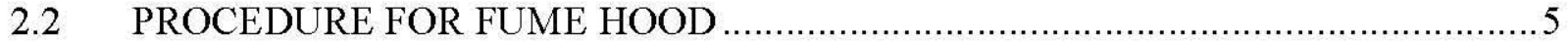

2.3 PROCEDURE FOR HOT CELL LOAD IN/LOAD OUT ……....................................

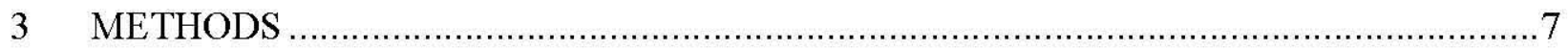

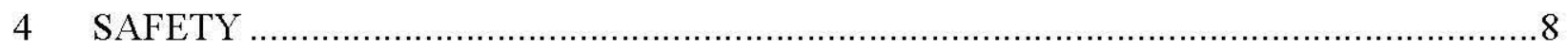

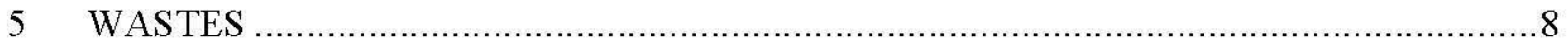

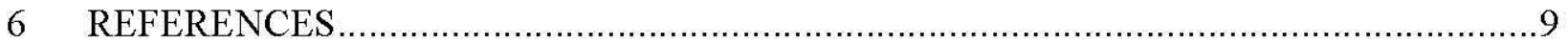

APPENDIX A. MPCMS SYSTEM ACTIVE PROBE DETAIL ....................................... A-i

\section{List of Tables}

Table 1. Weights of Bars, Round Coupons, and Stressed C-Rings Prior to Insertion into

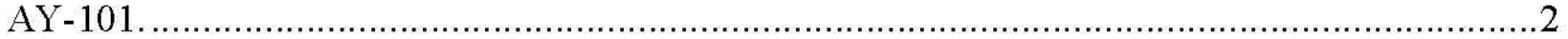

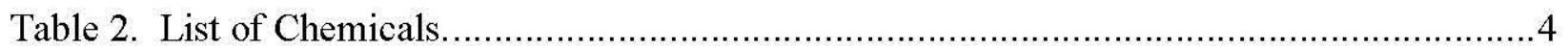

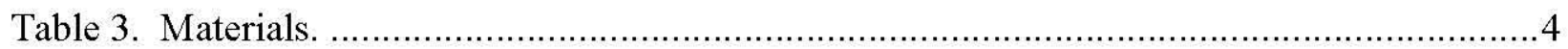

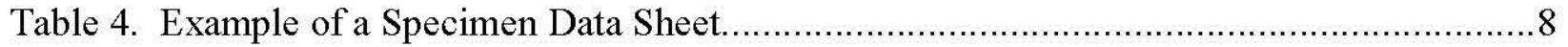

\section{List of Terms}

\section{Abbreviations}

ALARA As Low As Reasonably Achievable

AY-101 tank 241-AY-101

ARES Applied Research and Engineering Sciences

ASTM American Society for Testing and Materials

CAS Chemical Abstracts Service

$\mathrm{CH} \quad$ contact handled 
MPCMS Multi-Probe Corrosion Monitoring System

NIST National Institute of Standards and Technology

SEM scanning electron microscopy

USQ Unreviewed Safety Question

\section{Unit}

${ }^{\circ} \mathrm{C} \quad$ degrees Centigrade

$\mathrm{cm} \quad$ centimeter

g $\quad \operatorname{gram}(\mathrm{s})$

in. inch

M moles per liter

$\mu \mathrm{m} \quad$ micrometers

$\mathrm{v} / \mathrm{v} \quad$ volume to volume ratio 


\section{INTRODUCTION}

This test plan describes the methods to be used in the forensic examination of the Multi-probe Corrosion Monitoring System (MPCMS) installed in the double-shell tank 241-AY-101 (AY-101). The probe was designed by Applied Research and Engineering Sciences (ARES) Corporation ${ }^{1}$. The probe contains four sections, each of which can be removed from the tank independently (H-14-107634, AY-101 MPCMS Removable Probe Assembly) and one fixed center assembly. Each removable section contains three types of passive corrosion coupons: bar coupons, round coupons, and stressed C-rings (H-14-107635, AY-101 MPCMS Details). Photographs and weights of each coupon were recorded and reported on drawing H-14-107634 and in RPP-RPT-40629, 241-AY-101 MPCMS C-Ring Coupon Photographs. The coupons will be the subject of the forensic analyses.

The purpose of this examination will be to document the nature and extent of corrosion of the 29 coupons. This documentation will consist of photographs and photomicrographs of the $\mathrm{C}$-rings and round coupons, as well as the weights of the bar and round coupons during corrosion removal. The total weight loss of the cleaned coupons will be used in conjunction with the surface area of each to calculate corrosion rates in mils per year. The bar coupons were presumably placed to investigate the liquid-air-interface. An analysis of the waste level heights in the waste tank will be investigated as part of this examination.

The passive probe $\# 1$ will be removed from AY-101, washed with hot water to remove tank waste, sprayed with inhibited water $(0.01 \underline{\mathrm{M}}$ sodium hydroxide, $0.011 \underline{\mathrm{M}}$ sodium nitrite) to limit corrosion during transit, cut into sections, and packaged for shipping. The sections will be transported to the 222-S Laboratory for metrology and metallographic examination.

Table 1 shows the recorded weights before insertion into AY-101. Appendix A contains Drawings H-14-107634 and H-14-107635.

The customer has determined that this effort is not a Treatability Study under the Resource Conservation and Recovery Act. The Treatability Study Form, as well as the Waste Stream Fact Sheets, Radiological Work Activity Screening, Unreviewed Safety Question (USQ), and Compatibility Review Forms are contained in the project files.

\footnotetext{
${ }^{1}$ ARES Corporation Richland Office, 1100 Jadwin Avenue, Suite 400, Richland, WA 99352.
} 
Table 1. Weights of Bars, Round Coupons, and Stressed C-Rings Prior to Insertion into AY-101.

\begin{tabular}{|c|c|c|}
\hline \multicolumn{3}{|c|}{ Vapor Space Section } \\
\hline Reference Number & Coupon Type & Weight, g \\
\hline $280.63-1$ & C-Ring & 49.083 \\
\hline $286.63-1$ & Round & 21.677 \\
\hline $292.63-1$ & C-Ring & 49.193 \\
\hline $298.63-1$ & Round & 21.197 \\
\hline $304.63-1$ & C-Ring & 49.206 \\
\hline $310.63-1$ & Round & 21.930 \\
\hline \multicolumn{3}{|c|}{$\begin{array}{l}\text { Vapor Space-Supernate Interface Section } \\
\end{array}$} \\
\hline Reference Number & Coupon Type & Weight, $\mathrm{g}$ \\
\hline $366.75-1$ & Bar & 672.945 \\
\hline $387.75-1$ & Bar & 674.219 \\
\hline $408.75-1$ & Bar & 670.610 \\
\hline $429.75-1$ & Bar & 672.686 \\
\hline $450.75-1$ & Bar & 663.202 \\
\hline \multicolumn{3}{|c|}{ Supernate Section } \\
\hline Reference Number & Coupon Type & Weight, g \\
\hline $473.00-1$ & C-Ring & 49.048 \\
\hline $492.89-1$ & Round & 21.856 \\
\hline $512.77-1$ & C-Ring & 48.841 \\
\hline $532.66-1$ & Round & 21.581 \\
\hline $552.54-1$ & C-Ring & 49.358 \\
\hline $572.43-1$ & Round & 20.606 \\
\hline \multicolumn{3}{|c|}{ Supernate and Sludge Section } \\
\hline Reference Number & Coupon Type & Weight, $g$ \\
\hline $592.31-1$ & C-Ring & 49.168 \\
\hline $612.20-1$ & Round & 22.273 \\
\hline $632.08-1$ & C-Ring & 49.317 \\
\hline $651.97-1$ & Round & 22.136 \\
\hline $671.85-1$ & C-Ring & 49.536 \\
\hline $691.74-1$ & Round & 21.864 \\
\hline \multicolumn{3}{|c|}{ Sludge Section } \\
\hline Reference Number & Coupon Type & Weight, $g$ \\
\hline $708.00-1$ & C-Ring & 49.520 \\
\hline $710.92-1$ & Round & 22.124 \\
\hline $713.84-1$ & C-Ring & 49.440 \\
\hline $716.76-1$ & Round & 22.269 \\
\hline $719.68-1$ & C-Ring & 49.376 \\
\hline $722.60-1$ & Round & 21.668 \\
\hline
\end{tabular}




\section{CORROSION TREE BREAKDOWN PROCEDURE}

A photographic record will be maintained throughout the course of the analyses. These photographs will include macrophotography, optical microphotography, and scanning electron microphotography. Macrophotography will be used to document all of the recovered specimens and their general appearance upon recovery. Additional photographs will be taken of features of interest, such as large areas of corrosion and the crack area of the pre-cracked C-rings. The macrophotography will include a size scale for comparison. Selected bar coupons, round coupons, and C-rings will also be photographed and examined before, during, or after cleaning, weighing, cutting, and polishing. Features of interest will be documented using scanning electron microscopy (SEM). Specimens selected will include several coupons that display the range of corrosion types in which the extent of corrosion can be observed, as well as the three pre-cracked C-rings and one uncracked C-ring.

It is anticipated that the hot water wash will be sufficient to allow the supernate and solids/sludge sections of the probe to be contact handled $(\mathrm{CH})$. If this is not the case, then the sections that are not amenable to $\mathrm{CH}$ will be transferred to a hot cell for coupon disassembly. The hot cell that may be used will be at the discretion of the manager of Special Analytical Services. Coupons will be removed in the hot cell, rinsed, dried, and loaded out for weighing, cleaning, and photographic documentation.

\subsection{CHEMICALS AND MATERIALS}

The following sections delineate the chemicals and materials that will be used for the examination of the MPCMS coupons.

\subsubsection{Chemicals}

The chemicals to be used are listed in Table 2 by name and Chemical Abstracts Service (CAS) or Material Safety Data Sheet (MSDS) identification number. 
Table 2. List of Chemicals.

\begin{tabular}{|l|l|}
\hline \multicolumn{1}{|c|}{ Chemical } & \multicolumn{1}{|c|}{ CAS or Hanford MSDS Identification } \\
\hline $\begin{array}{l}\text { Inhibited water }(0.01 \mathrm{M} \text { sodium hydroxide }+ \\
0.011 \underline{\mathrm{M}} \text { sodium nitrite) }\end{array}$ & $\begin{array}{l}\text { Sodium hydroxide 1310-73-2 } \\
\text { Sodium nitrite 7632-00-0 }\end{array}$ \\
\hline Diammonium citrate & $3013-65-5$ \\
\hline Buehler ${ }^{\text {B2 }}$ blade coolant (petroleum distillate) & $64742-47-8$ \\
\hline $\begin{array}{l}\text { Nital solution (97 parts methanol : 3 parts } \\
\text { concentrated nitric acid; by volume) }\end{array}$ & Methanol 67-56-1 \\
\hline Liquid nitrogen & $7727-37-9$ \\
\hline Buehler epoxy resin & 010015 (MSDS) \\
\hline Buehler epoxy hardener & 010016 (MSDS) \\
\hline
\end{tabular}

\subsubsection{Materials}

Table 3 lists the materials that will be used in the examination of the MPCMS coupons.

Table 3. Materials.

\begin{tabular}{|c|}
\hline $\begin{array}{r}\text { Item Description } \\
\end{array}$ \\
\hline Brush with stiff plastic bristles \\
\hline Disposable towels \\
\hline $\begin{array}{l}\text { Pig }^{1 B 3} \text { heavy weight gray universal mat pads } \\
\text { (Pigmatting) }\end{array}$ \\
\hline $500 \mathrm{~mL}$ PYREX ${ }^{(\mathrm{B} / 4}$ \\
\hline Plastic tongs \\
\hline Ultrasonic bath \\
\hline Mettler balance \\
\hline Binocular optical microscope \\
\hline Lidded storage containers \\
\hline Hot plate \\
\hline Buehler IsoMet ${ }^{(B 5}$ saw \\
\hline $\begin{array}{l}\text { Buehler polishing wheel with polishing } \\
\text { cloths and diamond paste }\end{array}$ \\
\hline Desiccator \\
\hline
\end{tabular}

${ }^{2}$ The Buehler name is a registered trademark of Buehler Ltd., Lake Bluff, Illinois.

${ }^{3} \mathrm{Pig}$ is a registered trademark of New Pig, Titipon, Pennsylvania.

${ }_{5}^{4}$ PYREX is a registered trademark of Corning Incorporated, Corning, New York.

${ }^{5}$ IsoMet is a registered trademark of Buehler, Ltd., Lake Bluff, Illinois. 


\subsection{PROCEDURE FOR FUME HOOD}

Steps 1 through 17 below will be carried out in a fume hood (unless dose rates necessitate the use of a hot cell as described in Section 2.2). Step 18 below will be conducted either in a hood (macrophotography), or on the Aspex Scanning Electron Microscope and Optical Microscopy workstation in Room $1 \mathrm{~A}$ or on the FEI SEM in Room B1-G at the 222-S Laboratory.

The original mass of all the items to be examined has already been recorded, so the current process will begin by weighing each item, determining the post recovery mass, and recording that number. The inspection of the coupons using Steps 1 through 18 will conform to the guidance contained in the referenced American Society for Testing and Materials (ASTM ${ }^{\circledR 6}$ ) procedures (ASTM G1-03, Standard Practice for Preparing, Cleaning, and Evaluating Corrosion Test Specimens; ASTM G46-94, Standard Guide for Examination and Evaluation of Pitting Corrosion; ASTM E407-99, Standard Practice for Microetching Metals and Alloys; and ASTM E3-11, Standard Guide for the Preparation of Metallographic Specimens). Photographs will be obtained as needed during disassembly of the sections to document the condition of each section and individual specimen. A blank piece of steel will serve as a control and will be cleaned, weighed, and photographed in the same manner as the specimens to ensure that the cleaning solution results in minimal damage to the metal surfaces.

It is important that Steps 1 through 5 (below) be carried out as quickly as possible after retrieval, rinsing, and packaging of the probe sections in the tank farm. However, the timing of these steps will be dependent on radiological conditions during receipt and disassembly at the 222-S Laboratory. Every attempt will be made to expedite these steps, while maintaining as low as reasonably achievable (ALARA) standards. The length of time from packaging in the field to desiccation of the removed specimens will be recorded, and any delays will be explained.

1. Remove the corrosion probe sections from the shipping container.

2. Carefully remove the C-ring, round, and bar specimens from the probe body.

3. Rinse specimens with inhibited water, if necessary.

4. Pat dry with paper towels and place specimens in labeled containers.

5. Store specimens in a desiccator when they are not being examined. Leave tops off of specimen containers until samples are completely dry.

6. Weigh and record weight of each specimen.

7. Obtain macroscopic and microscopic photographic documentation of the rinsed specimens.

8. Soak in a glass beaker with the diammonium citrate solution for no more than $20 \mathrm{~min}$ on a hot plate set to approximately $80 \pm 5^{\circ} \mathrm{C}$.

\footnotetext{
${ }^{6}$ ASTM is a registered trademark of the American Society for Testing and Materials International, West Conshohocken, PA.
} 
9. Using a stiff bristle brush, remove as much corrosion as possible.

10. Rinse the specimen with inhibited water, pat dry, or oven dry if necessary $\left(60^{\circ} \mathrm{C}\right.$ or lower).

11. Cool in the desiccator for at least $1 \mathrm{hr}$ and weigh. Record weight.

12. If the weight loss is significant $(>1.0 \%$ ), continue the soak, brush, and weigh cycle until the weight change is less than $10 \%$ of the cumulative weight loss.

13. After the final weighing, dry the specimens thoroughly; if necessary, use an oven set to less than $60{ }^{\circ} \mathrm{C}$. Store in capped containers in a desiccator.

14. Examine selected bar, round, and C-ring coupons using binocular microscopy and/or SEM. Document crack and pitting shape, size, and density photographically.

15. Select the specimens which show the greatest evidence of corrosion. These specimens will be prepared for metallographic analysis.

16. Preparation Step 16a will be used for selected bar, round, or C-rings to document pitting; Steps $16 \mathrm{~b}$ and $16 \mathrm{c}$ will be used for selected C-rings in order to document development of the pre-stressed crack.

a) Imbed selected specimens in freshly mixed epoxy and allow the epoxy to harden.

b) Cut sections off the selected specimens using the Buehler ${ }^{\mathbb{B}}$ IsoMet low speed saw.

c) Polish cut sections to 600-grit and examine by optical and/or scanning electron microscopy to document pit size, shape and location. Photographs of the polished crack region will be taken before and after etching for comparison to the pictures taken before deployment and the length of the crack will be measured.

d) Cut thin slices ( 0.125 to 0.25 in. thick) of selected C-ring specimens (not imbedded in epoxy) and immerse them in liquid nitrogen to continue the fracture to completion. The faces of the cracked surfaces exposed in this manner will be examined for texture.

e) Selected cut sections of C-ring specimens will be polished to 10 microns with diamond paste and then etched using a nital solution $(3 \% \mathrm{v} / \mathrm{v}$ nitric acid in methanol), rinsing afterwards with distilled water and drying. This highlights individual grain boundaries. Photographs of the polished crack region will be taken before and after etching.

17. Examine each specimen in cross-section or fracture surface to document the depth of pitting and the type of C-ring cracking to aid in distinguishing between fatigueor stress-corrosion cracking and type of pitting. 
18. Document these features photographically.

\subsection{PROCEDURE FOR HOT CELL LOAD IN/LOAD OUT}

The use of a hot cell will be required depending upon the dose associated with any probe section. The load in/load out for the hot cell (if used) will be carried out in accordance with the most current revision of ATS-LO-100-110, "222-S Laboratory Cubicle Airlock Operation for 1A, 1F, $1 \mathrm{E}-1$, and 1E-2."

\section{METHODS}

Quality Control/Quality Assurance for the SEM will entail the following: National Institute of Standards and Technology (NIST) traceable microspheres will be used. The NIST traceable standards are 1,10 , and $100 \mu \mathrm{m}$ monosized microspheres procured through Thermo Scientific ${ }^{\circledR 7}$. Sample preparation for the SEM will follow ATS-LT-161-100, "222-S Laboratory Sample Preparation and Operating Procedure for Scanning Electron Microscopes." Balance calibration will be under ATS-LO-140-008, "Routine Use and Quality Assurance for Analytical Balances at 222-S Laboratory Complex."

Photographic documentation of the as-received probe sections will specifically include documentation of the condition of the bar coupons. The appearance and location of any features that could be attributed to corrosion at the vapor/liquid interface will be documented to the best degree possible prior to removal of the bar coupons.

Macro photographs and SEM microphotographs of the polished crack region will be taken before and after etching in a manner that will allow comparison to the pictures taken before deployment (RPP-RPT-40629) and the length of the crack will be accurately measured. Estimation of predeployment crack length from the photographs provided in RPP-RPT-40629 will not be performed as part of these tests.

The corrosion rate will be calculated using the following formula (ASTM ${ }^{\circledR}$ G1-03):

$$
\text { Corrosion Rate }=(K * W) /(A * T * D)
$$

Where:

$K=$ constant (use 3.45E06 for mils per year)

$T=$ time of exposure in hours

$A=$ area in $\mathrm{cm}^{2}$

$W=$ mass loss in grams

\footnotetext{
${ }^{7}$ Thermo Scientific is a registered trademark of Thermo Fisher Scientific, Inc., Waltham, Massachusetts.
} 


$$
D=\text { density in } \mathrm{g} / \mathrm{cm}^{3}
$$

The raw data and photographic inspection results will be documented in a report within 60 days of the completion of the laboratory analysis. The report will also contain observations on secondary inspection results such as glass seals, O-rings, probe body, etc. The data sheet shown in Table 4 will be filled out for each specimen and will be included in an appendix attached to the final report.

Table 4. Example of a Specimen Data Sheet.

\begin{tabular}{|c|c|c|c|c|c|}
\hline $\begin{array}{c}\text { Coupon } \\
\text { Identification } \\
\text { (Probe section } \\
\text { and Mark) } \\
1\end{array}$ & $\begin{array}{c}\text { Weight before } \\
\text { Exposure to } \\
\text { AN-107 }\end{array}$ & $\begin{array}{c}\text { Weight before } \\
\text { Solution Soak }\end{array}$ & $\begin{array}{c}\text { Weight after } \\
\text { Solution Soak } \\
\mathbf{2}\end{array}$ & $\begin{array}{c}\text { Weight Delta } \\
\text { (\%) } \\
\mathbf{5}\end{array}$ & $\begin{array}{c}\text { Photograph } \\
\text { Identification } \\
\text { (Magnification } \\
\text { and Distance) } \\
\mathbf{6}\end{array}$ \\
\hline & & & & & \\
\hline & & & & & \\
\hline & & & & & \\
\hline & & & & & \\
\hline
\end{tabular}

\section{SAFETY}

The MSDS documentation is available for all reagents used in the execution of this test procedure. Except for the nital solution, none of the reagents used or procedures to be performed pose threats beyond those generally encountered in the routine chemical analysis of materials in the 222-S Laboratory.

The nital solution is corrosive and can potentially react if improperly mixed. Pour the nitric acid into the methanol slowly while stirring to ensure complete mixing. Make this solution in a fume hood while wearing proper protective gloves and appropriate protective clothing.

\section{WASTES}

Wastes from this process will be inhibited water, the soak solution, control specimens, test specimens, and hardened epoxy. All test specimens are retained for 60 days after the report is completed. Arrangements can be made to retain them longer if necessary. All wastes will be disposed of in accordance with the 222-S waste handling and management protocols (ATS-LO-100-151, "ATS Laboratory Waste Generation"). 


\section{REFERENCES}

AN-107-TP-1.0, 2006, Test Plan for the 241-AN-107 Integrated Multi-function Corrosion Probe, Rev. 0, CH2M HILL Hanford, Richland, Washington.

$\operatorname{ASTM}^{\circledR}$ G1-03, 2003, Standard Practice for Preparing, Cleaning, and Evaluating Corrosion Test Specimens, ASTM International, Conshohocken, Pennsylvania.

ASTM $^{\circledR}$ G46-94, 2005, Standard Guide for Examination and Evaluation of Pitting Corrosion, ASTM International, Conshohocken, Pennsylvania.

ASTM $^{\circledR}$ E407-99, 1999, Standard Practice for Microetching Metals and Alloys, ASTM International, Conshohocken, Pennsylvania.

ASTM $^{\circledR}$ E3-11, 2011, Standard Guide for the Preparation of Metallographic Specimens, ASTM International, Conshohocken, Pennsylvania.

ATS-LO-100-110, "222-S Laboratory Cubicle Airlock Operation for 1A, 1F, 1E-1, and 1E-2," as revised, Washington River Protection Solutions LLC, Richland, Washington.

ATS-LO-100-151, "Laboratory Waste Generation," as revised, Washington River Protection Solutions LLC, Richland, Washington.

ATS-LO-140-008, "Routine Use and Quality Assurance for Analytical Balances at 222-S Laboratory Complex," as revised, Washington River Protection Solutions LLC, Richland, Washington.

ATS-LT-161-100, "222-S Laboratory Sample Preparation and Operating Procedure for Scanning Electron Microscopes," as revised, Washington River Protection Solutions LLC, Richland, Washington.

H-14-107634, Sheet 1, 2009, AY-101 MPCMS Removable Probe Assembly, Rev. 1, Office of River Protection, Richland, Washington.

H-14-107635, Sheet 1, 2009, AY-101 MPCMS Details, Rev. 0, Office of River Protection, Richland, Washington.

RPP-RPT-40629, 2009, 241-AY-101 MPCMS C-Ring Coupon Photographs, Rev. 0, ARES Corporation for Washington River Protection Solutions LLC, Richland, Washington. 
LAB-PLAN-12-00005 R0

\section{APPENDIX A}

MPCMS SYSTEM ACTIVE PROBE DETAIL 
LAB-PLAN-09-00005 R0

Appendix A

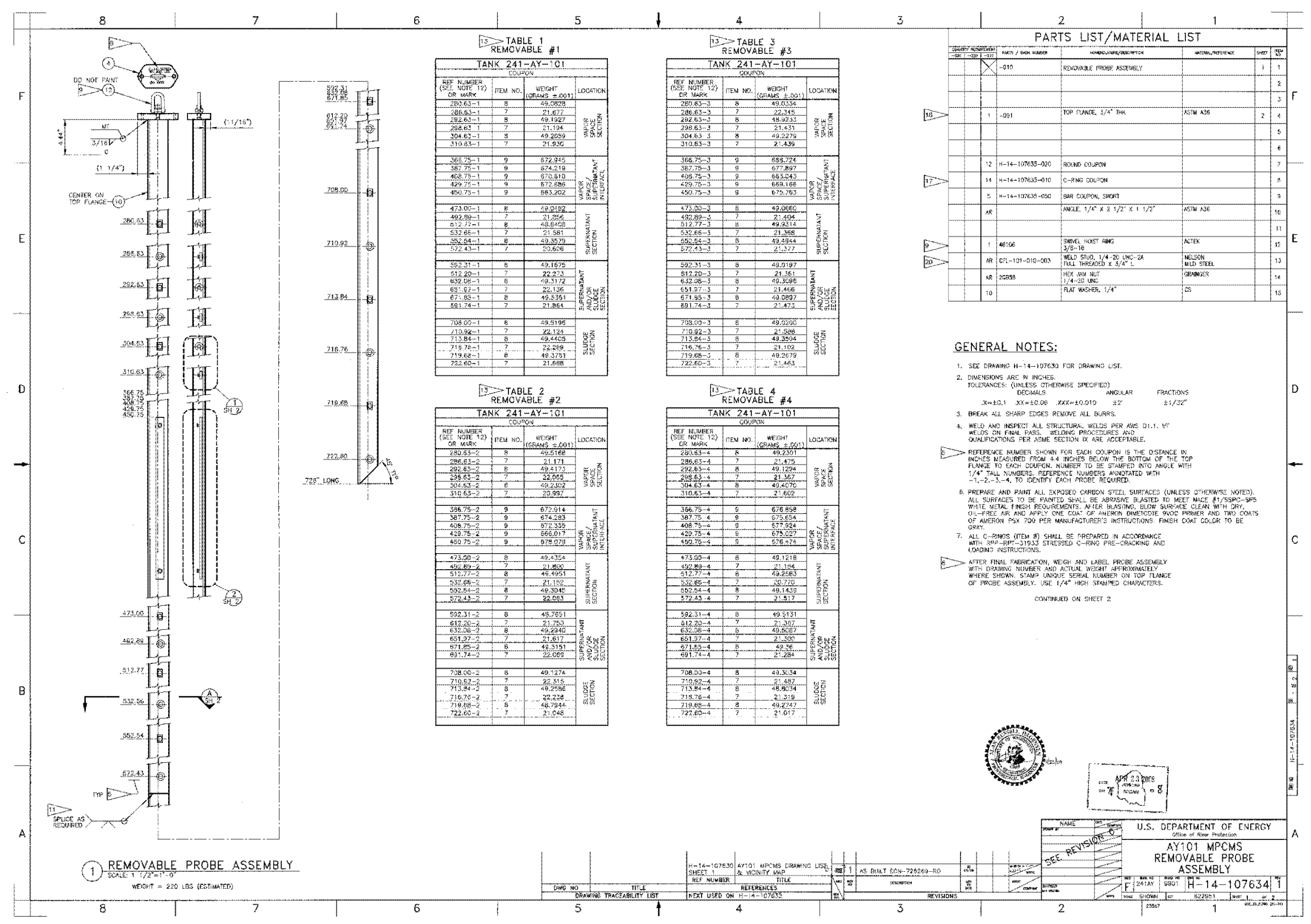


LAB-PLAN-09-00005 R0

Appendix A

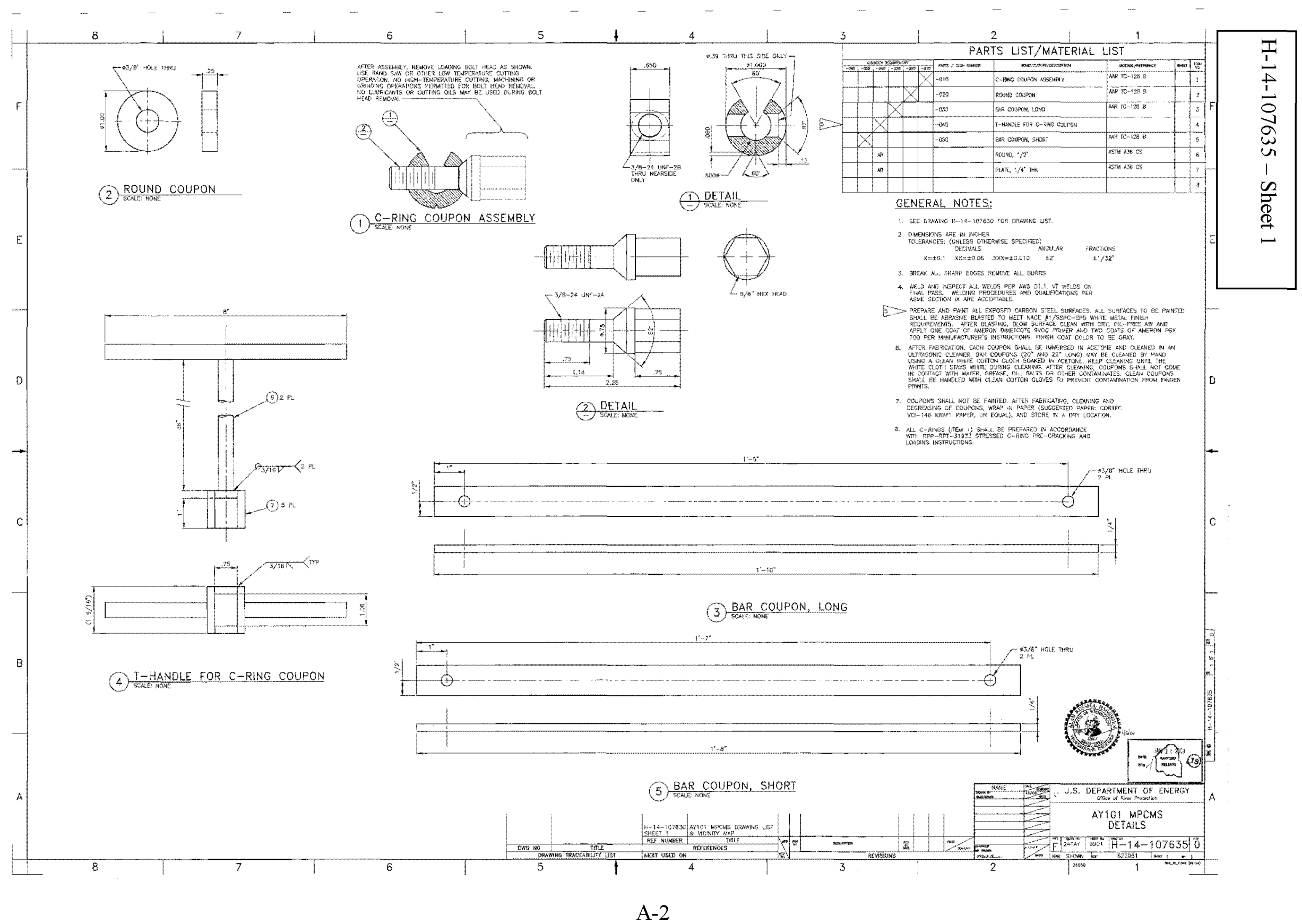




\section{Electronically Approved by:}

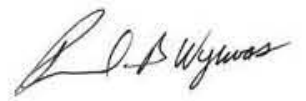

UserName: Wyrwas, Richard (h3390899)

Title: APD Chemist

Date: Monday, 05 March 2012,03:42 PM Pacific Time

Meaning: Approved by the author or delegate

UserName: Cooke, Gary (h0410221)

Title: APD Chemist

Date: Tuesday, 06 March 2012, 06:27 AM Pacific Time

Meaning: Additional approval obtained

UserName: Page, Jason (h2841343)

Title:

Date: Tuesday, 06 March 2012, 07:23 AM Pacific Time

Meaning: Additional approval obtained

UserName: Castleberry, Jim (h0051558)

Title:

Date: Tuesday, 06 March 2012, 07:38 AM Pacific Time

Meaning: Approved by the customer or delegate

UserName: Hardy, Don (h0085161)

Title: Laboratory Facilities Manager

Date: Tuesday, 06 March 2012, 08:37 AM Pacific Time

Meaning: Approved by the Facility Manager or delegate 


\section{Electronically Approved by:}

UserName: Seidel, Cary (h0009079)

Title: APD Manager

Date: Wednesday, 07 March 2012, 11:49 AM Pacific Time

Meaning: Approved by the Group Manager or delegate 